\title{
Retirement and Productivity Age in Indonesia: HRM and Indonesian Law Perspectives
}

\author{
Regina Deti ${ }^{1}$, Virginia Mandasari ${ }^{2}$ \\ 1Universitas Katolik Parahyangan, Indonesia \\ 2UPN “Veteran” Jawa Timur, Indonesia
}

\begin{abstract}
To increase the productivity of their companies, some companies in Indonesia choose to reduce the retirement age of their employees, considering that the productive age group is currently only 1535 years old. This research wants to find out how the decision is made from the perspective of human resource management and the policy context of the Indonesian government. The collection of data from the literature review used in this research includes journals, books, archives and regulatory policies, which is a way to solve problems by conducting searches on research that has been made previously. This research states that there is no appropriate retirement age for all industries.
\end{abstract}

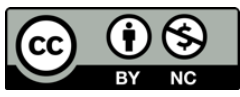

This is an open access article under the CC-BY-NC license.

\section{INTRODUCTION}

In Indonesia, as many as $70 \%$ of the population are residents of the productive age group (www.kompas.id). The term productivity is used as a measure of the comparison between output and several sources used to produce inputs (Barnes, 1980). According to BPS, those who are included in the productive age are in the age range of 15 to 64 years (www.bps.go.id). But in reality, people in Indonesia can only work after 17 years. Similar to the difference in theory and reality that occurs at the lower limit, there is also a shift in the upper limit regarding the age of productivity, which affects the policy of a company to determine the age limit for retirement.

Although BPS states that the productive age in Indonesia is 15-64 years, it can also be assumed that at the end of the productive age, productivity will decline and can hamper the economic growth of a company (Skirbekk, 2004). According to Skirbekk (2004), this has prompted several studies on regulations regarding changes in the age limit for retirement, which are planned before the end of productive age.

Some companies set the retirement age of their employees from 50 years to 65 years depending on the type of company and the work they do. Determination of retirement age is usually closely related to company productivity, because to increase productivity, what can be done is an increase made by humans (Siagan, 2002). So to increase the productivity of their companies, some companies choose to reduce the retirement age of their employees, considering that Yoris Sebastian in RealiseInsider stated that the productive age group is currently only 15-35 years old.

Factors that affect work productivity include age, education, work experience (Utami, 2015), gender and motivation. According to Utami (2015), age is one of the main factors in the ability of an employee to be productive. Ukkas (2017) mentions that the productive age of 15-50 years is the age stage where humans can adapt well to their environment and can understand technology easily. However, age level is also very closely related to how stamina a worker is in the workload given to him. The older the worker, it can be assumed that the productivity of the worker will decrease (Ukkas, 2017). 


\section{LITERATURE REVIEW}

\section{Human Resource Management}

Human resource management is a science to learn about a series of organizational activities directed at attracting, developing and retaining an effective workforce (Fahmi, 2016). According to Bangun (2012), human resource management is a science to know more about the process of planning, organizing, staffing, mobilizing, planning, maintaining and separating the workforce to achieve the organization's vision and mission. According to Alami et al. (2015), human resource management has an important role to increase effectiveness in an organization. Human resource management also has an important role because it is used as a reference for relocating and terminating employees (Alami et al. 2015) as well as as a reference for setting strategies and as a measuring tool for evaluating employee performance evaluation and employee productivity (Andersson, 2007). In the science of human resource management, there are several theories that are used as a reference for measuring age. The theory that is widely used is the theory of worker productivity. The role of human resources is considered very important to productivity because human resources are one of the main elements of the organization to achieve its goals (Wartana, 2011).

Kenietal. (2013) stated that changes to the retirement age policy can affect three kinds of commitments, namely affective commitment, continuance commitment, and normative commitment as depicted in Figure 2.1. Policies can affect each worker differently, research conducted by Keniatal. (2013) added that each worker will have a different perception of retirement age which for some workers of retirement age can have a greater effect than for other workers. However, several studies have shown that changes in the retirement age will definitely affect the productivity and commitment of workers to the company (Kenietal, 2013).

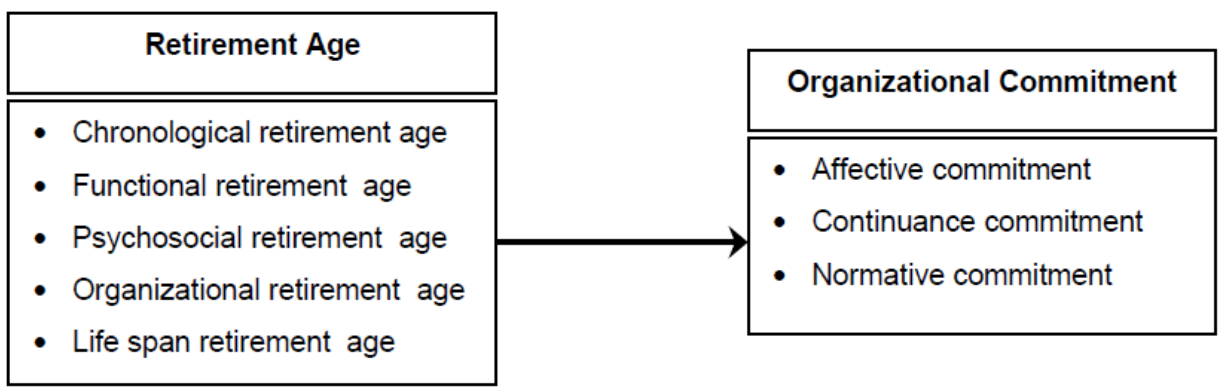

Figure 1. Effect of Retirement Age on Employee Commitment

\section{RESEARCH METHODOLOGY}

In an effort to get some perspectives on productive age in human resource management, the method used is the literature review method. The collection of data from the literature review used in this research includes journals, books, archives and regulatory policies, which is a way to solve problems by conducting searches on research that has been made previously. Literature review data collection is used with thematic structure sequence. The collection of literature reviews will use several stages including searching for articles based on outlines and grouping based on relevance to the topic and year of research, then sorting the explanatory structure and comparison of interconnected data.

Literature review searches, especially journals and articles, were conducted without limiting the time of publication and using keywords including "productive age", "productivity factor", and "the effect of working age" which were identified based on the relevance of journal content and topic relevance. After the journals and articles have been collected, the number of articles that have been obtained is grouped based on the relevance of the topic regarding the age of productivity in the workforce. The search for journals and articles is not limited to the year of publication, but journals and articles with the latest year's publication will be prioritized as the latest research.

Based on the search, several relevant journals were obtained and according to the topic of discussion. The journals and articles are sorted and arranged into a table with only 19 titles with publications in the last 10 years. These journals are used to discuss and compare research according to topics based on their relevance. Then the journals that have been grouped will be analyzed for their explanations and compared their relationships. The addition of other journals, articles, and books is to strengthen and increase the sharpness of the discussion of research results. Analysis of the results of these journals uses 
the critical appraisal method. The critical appraisal method is a journal analysis process that is used as a theoretical basis regarding the differences, similarities, and shortcomings of the journals used. The journal will then be reviewed to select the measurement results that are appropriate to the topic.

\section{FINDINGS DISCUSSION}

\section{Law of the Republic of Indonesia Number 13 of 2003 concerning Manpower}

The central regulation that regulates the retirement age is the Law of the Republic of Indonesia Number 13 of 2003 concerning Manpower. The law as a whole was made in order to realize several things as follows.
a) Development of Indonesian society to create a just, prosperous, prosperous society, which is both materially and spiritually equitable;
b) Manpower development to improve the quality of the workforce;
c) Protection of workers to ensure the basic rights of workers/laborers;
d) And to ensure equal opportunity and treatment without discrimination.

The Law of the Republic of Indonesia Number 13 of 2003 contains matters concerning employment in Indonesia as follows:
a) Work training;
b) Employment opportunities and fair treatment;
c) Employment placement;
d) Expansion of job opportunities;
e) Work relationship;
f) Work protection;
g) Wages and welfare work;
h) Industrial relations;
i) Work termination;
j) Coaching;
k) Investigations;
l) Criminal provisions;
m) Administrative sanctions.

Determination of retirement age is regulated in the Law of the Republic of Indonesia Number 13 of 2003 concerning Manpower. Based on the Law of the Republic of Indonesia No. 13 of 2003, it is stated in Article 154 Letter C.

\footnotetext{
"Workers/laborers reach retirement age in accordance with the provisions in the employment agreement, company regulations, collective labor agreements, or statutory regulations"
}

The above statement which is mandated by the applicable law shows that basically the retirement age owned by each employee is adjusted to the cooperation agreement mutually agreed upon by the employee/worker and the company. Furthermore, the retirement age ideally needs to be adjusted to the workload of the employee/employee for the position/position held. Specifically, this is studied in the science of human resource management. In addition to determining the retirement age, the Law of the Republic of Indonesia Number 13 of 2003 also explains about severance pay and pension benefits. Employers can terminate the employment relationship of workers/laborers because they are of retirement age and if the employer has enrolled the worker/laborer in a pension program whose contributions are fully paid by the entrepreneur, then the worker/laborer is not entitled to receive severance pay according to the provisions of Article 156 paragraph (2), the reward for service period is in accordance with the provisions of Article 156 paragraph (3), but the compensation for entitlements is still in accordance with the provisions of Article 156 paragraph (4).

\section{Law of the Republic of Indonesia Number 40 of 2004 concerning the National Social Security System}

In addition to Law of the Republic of Indonesia Number 13 of 2003, other regulations issued by the Government of Indonesia regarding issues in employment are regulated in Law of the Republic of Indonesia Number 40 of 2004. Law of the Republic of Indonesia Number 40 of 2004 specifically regulates the pension system for employees which also explains the objectives of the National Social 
Security System, the programs provided to national insurance participants, as well as the benefits obtained for participants.

\section{Government Regulation of the Republic of Indonesia Number 45 of 2015 concerning the Implementation of the Pension Guarantee Program}

In addition to RI Law Number 13 of 2003 and RI Law Number 40 of 2004, regulations relating to labor pensions are regulated in Government Regulation of the Republic of Indonesia Number 45 of 2015 concerning the Implementation of the Pension Guarantee Program. In PP No. 45 of 2015 it is regulated regarding participation and registration procedures for pension insurance programs, pension benefits, contributions, and supervision. There are differences between the regulations in Law Number 13 of 2003 and Government Regulation Number 45 of 2015 regarding the retirement age of employees/workers. Law Number 13 of 2003 does not specifically stipulate the age limit for employees, while in PP Number 45 of 2015 it is specifically regulated in Article 15 paragraphs (1), (2), (3), and (4) as follows.

(1) "For the first time, the retirement age is set at 56 (fifty-six) years"

(2) "Starting January 1, 2019, the Retirement Age as referred to in paragraph (1) will be 57 (fifty-seven) years"

(3) "The retirement age as referred to in paragraph (2) will be increased by 1 (one) year for every 3 (three) years until it reaches the retirement age of 65 (sixty-five) years."

(4) "In the event that a Participant has entered the Retirement Age but he/she is still employed, the Participant may choose the Retirement Age or at the time of cessation of work with the provisions of a maximum of 3 (three) years after the Retirement Age."

\section{Retirement Age Policy in Human Resource Management Science Perspective}

There are 19 literatures that discuss productivity age as a research for determining retirement age. All of these journals are national and international journals which were searched using the keywords "age productivity", "retirement age", and "worker productivity" which were then analyzed using critical appraisal analysis to analyze the core journals and research results so that they could find out the similarities and differences between them. are in these journals. The summaries of 19 journals are summarized in the critical appraisal analysis table as follows.

Table 1 Analisis Critical Appraisal

\begin{tabular}{c|l|l}
\hline No. & Author, Year and Title & Discussion \\
\hline 1. & $\begin{array}{l}\text { Afonso et al. 2020. } \\
\text { Labour Productivity in State-Owned } \\
\text { Enterprises. }\end{array}$ & Factors affecting worker productivity. \\
\hline 2. & $\begin{array}{l}\text { Aiyaretal. 2016. } \\
\text { The Impact of Workforce Aging on European } \\
\text { Productivity. }\end{array}$ & $\begin{array}{l}\text { The effect of worker aging on labor } \\
\text { productivity. }\end{array}$ \\
\hline 3. & $\begin{array}{l}\text { Anwar and Farmawati. 2018. } \\
\text { Pengaruh Jumlah Penduduk Usia Produktif, } \\
\text { Kemiskinan dan Inflasi terhadap Pertumbuhan } \\
\text { Ekonomi di Kabupaten Bireuen. }\end{array}$ & $\begin{array}{l}\text { Knowing the effect of the large population } \\
\text { of productive age, poverty and inflation on } \\
\text { economic growth. }\end{array}$ \\
\hline 4. & $\begin{array}{l}\text { Aprilyanti. 2017. } \\
\text { Pengaruh Usia dan Masa Kerja Terhadap } \\
\text { Produktivitas Kerja (Studi Kasus: PT. OASIS } \\
\text { Water Internatinal Cabang Palembang). }\end{array}$ & $\begin{array}{l}\text { Age and tenure as factors directly related } \\
\text { to work productivity. }\end{array}$ \\
\hline 5. & $\begin{array}{l}\text { Boring and Grogaard. 2021. } \\
\text { Do Older Employees Have a Lower Individual } \\
\text { Productivity Potential than Younger } \\
\text { Employees? }\end{array}$ & $\begin{array}{l}\text { Analyze the relationship between } \\
\text { employee age and individual productivity } \\
\text { potential. }\end{array}$ \\
\hline 6. & $\begin{array}{l}\text { Gobel and Zwick. 2011. } \\
\text { Age and Productivity - Sector Differences. }\end{array}$ & $\begin{array}{l}\text { Measuring the impact of changes in a } \\
\text { company's age structure on productivity } \\
\text { using a representative panel of related }\end{array}$ \\
\hline
\end{tabular}




\begin{tabular}{|c|c|c|}
\hline No. & Author, Year and Title & Discussion \\
\hline & & employee data. \\
\hline 7. & $\begin{array}{l}\text { Hasanah and Widowati. } 2011 . \\
\text { Analisis Produktivitas Tenaga Kerja pada } \\
\text { Industri Rumah Tangga Krecek di Kelurahan } \\
\text { Segoroyoso. }\end{array}$ & Analyzing labor productivity. \\
\hline 8. & $\begin{array}{l}\text { Kenietal. } 2013 . \\
\text { The Impact of Retirement Age on } \\
\text { Organizational Commitment. }\end{array}$ & $\begin{array}{l}\text { Explores the relationship between various } \\
\text { conceptualizations of retirement age and } \\
\text { organizational commitment. }\end{array}$ \\
\hline 9. & $\begin{array}{l}\text { Kumbadewi et al. } 2016 . \\
\text { Pengaruh Umur, Pengalaman Kerja, Upah, } \\
\text { Teknologi dan Lingkungan Kerja terhadap } \\
\text { Produktivitas Karyawan. }\end{array}$ & $\begin{array}{l}\text { To determine the simultaneous and partial } \\
\text { effect of age, work experience, wages, } \\
\text { technology, and work environment } \\
\text { variables on employee productivity. }\end{array}$ \\
\hline 10. & $\begin{array}{l}\text { Maria and Raharjo. 2020. } \\
\text { Adaptasi Kelompok Usia Produktif Saat } \\
\text { Pandemi Covid-19 Menggunakan Metode } \\
\text { Reality Therapy. }\end{array}$ & $\begin{array}{l}\text { To find out how the productive age group } \\
\text { adapts to the current Covid-19 pandemic } \\
\text { situation. }\end{array}$ \\
\hline 11. & $\begin{array}{l}\text { Nugraheni. } 2019 . \\
\text { Perspektif Kewilayahan Penduduk Usia } \\
\text { Produktif: Kasus Indonesia 1. }\end{array}$ & $\begin{array}{l}\text { The variability of the provinces in } \\
\text { Indonesia in their potential in } \\
\text { demographic differences. }\end{array}$ \\
\hline 12. & $\begin{array}{l}\text { Ozimek et al. } 2017 . \\
\text { Aging and The Productivity Puzzle. }\end{array}$ & $\begin{array}{l}\text { How the age of workers can affect } \\
\text { productivity. }\end{array}$ \\
\hline 13. & $\begin{array}{l}\text { Pranata. } 2018 . \\
\text { Pengaruh Pendidikan, Upah, Usia, dan Masa } \\
\text { Kerja terhadap Produktivitas Tenaga Kerja } \\
\text { (Studi Kasus pada Unit Industri Rokok Cerutu } \\
\text { Bobbin Kabupaten Jember). }\end{array}$ & $\begin{array}{l}\text { Discusses the level of education, wages, } \\
\text { age, and years of service on productivity. }\end{array}$ \\
\hline 14. & $\begin{array}{l}\text { Putri and Setiawina. } 2013 . \\
\text { Pengaruh Umur, Pendidikan, Pekerjaan } \\
\text { terhadap Pendapatan Rumah Tangga Miskin di } \\
\text { Desa Bebandem. }\end{array}$ & $\begin{array}{l}\text { To determine the effect of age, education } \\
\text { and type of work on income. }\end{array}$ \\
\hline 15. & $\begin{array}{l}\text { Rembiasz. } 2017 . \\
\text { Impact of Employee Age on the Safe } \\
\text { Performance of Production Tasks. }\end{array}$ & $\begin{array}{l}\text { Knowing the factors that affect work safety } \\
\text { as a step to improve work safety. }\end{array}$ \\
\hline 16. & $\begin{array}{l}\text { Rocha. } 2017 . \\
\text { Aging, Productivity and Wages: Is an Aging } \\
\text { Workforce a Burden to Firms? }\end{array}$ & $\begin{array}{l}\text { To find out whether workers with an older } \\
\text { age are a burden to the company because } \\
\text { they are considered to give excessive } \\
\text { salaries that are not in accordance with } \\
\text { their productivity. }\end{array}$ \\
\hline 17. & $\begin{array}{l}\text { Shehada and Dawood. } 2017 . \\
\text { Measuring the Relationship between Age and } \\
\text { Productivity: A case Research of Orange West } \\
\text { Sales Department. }\end{array}$ & $\begin{array}{l}\text { Measuring the relationship between } \\
\text { worker age and productivity. }\end{array}$ \\
\hline 18. & $\begin{array}{l}\text { Sunar. } 2012 . \\
\text { Pengaruh Faktor Biografis (Usia, Masa Kerja, } \\
\text { dan Gender) terhadap Produktivitas Karyawan } \\
\text { (Studi Kasus PT. Bank X). }\end{array}$ & $\begin{array}{l}\text { To discuss the relationship between } \\
\text { biographical factors on employee } \\
\text { productivity. }\end{array}$ \\
\hline 19. & $\begin{array}{l}\text { Ukkas. } 2017 . \\
\text { Faktor } \quad \text { Faktor yang Mempengaruhi } \\
\text { Produktivitas Tenaga Kerja Industri Kecil Kota } \\
\text { Palopo. }\end{array}$ & $\begin{array}{l}\text { To find out the factors that influence labor } \\
\text { productivity on the quality of production. }\end{array}$ \\
\hline
\end{tabular}

Based on several studies that have been compiled using the critical appraisal analysis method in Table 1 . above, it is found that age cannot be concluded as the main factor causing the decline in worker productivity. Although retirement age and its relation to productivity have become a global issue Longman, 2010), but there is no research that can conclude the right age as a reference for the 
retirement age limit for workers (Kenietal., 2013). Although there is no clear age limit as a reference, Rembiasz (2017) states that workers aged 50 years and over tend to make the company's economy decline because older workers usually have a longer working period so that in some companies these workers will receive an increase. the salary and health insurance provided, but the performance provided by the worker will decrease due to a decrease in the ability of the worker, especially in his physical ability.

The speed of aging that can occur is different for each worker (Kooijetal., 2008) which is one of the reasons why a worker's retirement age cannot be determined in general. Kenietal. (2013) stated that setting the retirement age in general will have an impact not only on productivity but also on work motivation and commitment of workers to the company. If the retirement age is determined at an age that is considered too young, workers will not have the loyalty and motivation to work for the company and after retirement will work for companies with a longer age range (Ours and Stoeldraijer, 2010). So the company's productivity will decline faster than it should, which is supported by Kenietal's research. (2013) if the employee's loyalty and motivation decreases due to coercion to retire even though on the other hand the worker still has the desire to be loyal to the company.

Accelerating or extending the retirement age of a worker has both positive and negative impacts. By extending the retirement age of workers, the company will experience a negative effect by increasing the costs incurred, but this can also have a positive impact. Workers who have loyalty to the company will strive for their productivity not to decrease much and increase their loyalty to the company (Kenietal., 2013).

\section{CONCLUSION AND FURTHER RESEARCH}

In closing, this research is expected to provide an overview of decision making regarding appropriate policies for determining retirement age, both based on existing policies in Indonesia and also based on the perspective of human resource management. This research is also expected to be a consideration for the government to make policies in more detail so that companies in Indonesia are not biased to interpret these policies. This research states that there is no appropriate retirement age for all industries. More in-depth research is needed using empirical research so that policies can be made regarding the appropriate retirement age according to each company, where one of the suggestions that can be given is to measure years of service and work performance rather than measuring it from chronological age.

Based on the studies that have been done, the authors suggest further studies using different methods and databases. Further research is needed to be able to see the position of research if it is applied to the actual situation to solve an existing problem. For future researchers, the results of this research can be used as a comparison chart and reference for research, and as a consideration to further deepen further research by using case studies and using problems to solve or find solutions

\section{REFERENCES}

Afonso, A., Guedes, M. J. Dan Patel, P. C. 2020. Labour Productivity in State-Owned Enterprises. EconPol Working Paper, 45(4).

Aiyar, S., Ebeke, C. dan Shao, X. 2016. The Impact of Workforce Aging on European Productivity. IMF WorkingPapers.

Anwar, K. dan Fatmawati. 2018. Pengaruh Jumlah Penduduk Usia Produktif, Kemiskinan dan Inflasi terhadap Pertumbuhan Ekonomi di Kabupaten Bireuen. Jurnal Ekonomi Regional Unimal, 1(1).

Aprilyanti, S. 2017. Pengaruh Usia dan Masa Kerja terhadap Produktivitas Kerja (Studi Kasus: PT. OASIS Water International Cabang Palembang). Jurnal Sistem dan Manajemen Industri, 1(2), hal. 68-72

Barth, M. C., McNaught, W. Dan Rizzi, P. 1993. Corporations and the Aging Workforce. Building the Competitive Workforce: Investing in Human Capital for Corporate Success, P. H. Mirvis ed. John Wileyand Sons.

Boring, P. dan Grogaard, J. B. 2021. Do Older Employess Have a Lower Individual Productivity Potential than Younger Employees? Journal of Population Ageing.

Garibaldi, P. J., Martins, O. dan Ours, J. C. 2010. Health, Longevity and Productivity, Oxford University Press, forthcoming.

Gobel, C. dan Zwick, T. 2011. Age and Productivity - Sector Differences? Discussion paper, No. 11-058. 
Hasanah, E. U. dan Widowati, P. 2011. Analisis Produktivitas Tenaga Kerja pada Industri Rumah Tangga Krecek di Kelurahan Segoroyoso. EFEKTIF Jurnal Bisnis dan Ekonomi, 2(2), hal. 169-182.

Keni, Muthuveloo, R., Huey, L. P. Dan Ping T. A. 2013. The Impact of Retirement Age on Organizational Commitment. International Conference on Entrepreneurship and Business Management (ICEBM 2013).

Kumbadewi, L. S., Suwendra I. W., dan Susila, G. P. A. J. 2016. Pengaruh Umur, Pengalaman Kerja, Upah, Teknologi dan Lingkungan Kerja terhadap Produktivitas Karyawan. E-Journal Bisma Universitas Pendidikan Ganesha, Vol. 4.

Maria, G. A. R. dan Raharjo, S. T. 2020. Adaptasi Kelompok Usia Produktif Saat Pandemi Covid-19 Menggunakan Metode RealityTherapy. Jurnal Kolaborasi Resolusi Konflik, 2(2), hal. 142-149.

Nugraheni, S. 2019. Perspektif Kewilayahan Usia Produktif: Kasus Indonesia 1.

Ours, J. C. dan Stoeldraijer, L. 2010. Age, Wage andProductivity. IZA Discussion Paper, 4765.

Ozimek, A., DeAntonio, D. dan Zandi, M. 2017. Aging and the Productivity Puzzle.

Pemerintah Indonesia. 2015. Peraturan Pemerintah Republik Indonesia Nomor 45 Tahun 2015 Tentang Penyelenggaraan Program Jaminan Pensiun. Lembaran Negara Republik Indonesia Tahun 2015 Nomor 155. Jakarta: Sekretariat Negara.

Pemerintah Indonesia. 2003. Undang-Undang Republik Indonesia Nomor 13 Tahun 2003 Tentang Ketenagakerjaan. Lembaran Negara Republik Indonesia Tahun 2003. Jakarta: Sekretariat Negara.

Pemerintah Indonesia. 2004. Undang-Undang Republik Indonesia Nomor 40 Tahun 2004 Tentang Sistem Jaminan Sosial Nasional. Lembaran Negara Republik Indonesia Tahun 2004 Nomor 150. Jakarta: Sekretariat Negara.

Pranata, H. 2018. Pengaruh Pendidikan, Upah, Usia, dan Masa Kerja terhadap Produktivitas Tenaga Kerja (Studi Kasus pada Unit Industri Rokok Cerutu Bobbin Kabupaten Jember). Fakultas Ekonomi dan Bisnis Universitas Brawijaya.

Putri, A. D. dan Setiawina, N. D. Pengaruh Umur, Pendidikan, Pekerjaan terhadap Pendapatan Rumah Tangga Miskin di Desa Bebandem. E-Jurnal EP Unud, 2(4), Hal. 173-180.

Rembiasz, M. 2017. Impact of Employee Age onthe Safe Performance of Production Tasks. MATEC Web Conferences.

Robbin, P. S. 1996. Perilaku Organisasi: Konsep, Kontroversi, dan Aplikasi. Terjemahan. Jakarta: PT. Prenhalindo.

Rocha, R. 2017. Aging, Productivity and Wages: Is an Aging Workforce a Burdento Firms? Revista Espacios, 38(39), Hal. 21.

Shehada, M. dan Dawood, W. A. 2017. MeasuringtheRelationshipbetween Age andProductivity: A Case Research ofOrangeWestSales Department. American BasedResearchJournal, 6(2), Hal. 2304-7151.

Sunar. 2012. Pengaruh Faktor Biografis (Usia, Masa Kerja, dan Gender) terhadap Produktivitas Karyawan (Studi Kasus PT. Bank X).

Yasin, M. dan Priyono, J. 2016. Analisis Faktor Usia, Gaji dan Beban Tanggungan terhadap Produksi Hoe Industri Sepatu di Sidoarjo (Studi Kasus di Kecamatan Krian). Jurnal Ekonomi \& Bisnis, 1(1), hal. 95-120.

Ukkas, I. 2017. Faktor - Faktor yang Mempengaruhi Produktivitas Tenaga Kerja Industri Kecil Kota Palopo. Kelola: Journal of Islamic Education Management, 2(2), Hal. 187-198. 